\title{
Recent Advances in Preventing Adverse Reactions to
}

\section{Transfusion [version 1; peer review: 4 approved]}

\author{
Thomas S Rogers ${ }^{1,2}$, Mark K Fung 1,2, Sarah K Harm ${ }^{1,2}$
}

${ }^{1}$ Blood Bank \& Transfusion Medicine, University of Vermont Medical Center, Burlington, Vermont, 05401, USA

${ }^{2}$ Department of Pathology and Laboratory Medicine, University of Vermont College of Medicine, Burlington, Vermont, 05401, USA

V1 First published: 17 Dec 2015, 4(F1000 Faculty Rev):1469

https://doi.org/10.12688/f1000research.7048.1

Latest published: 17 Dec 2015, 4(F1000 Faculty Rev):1469

https://doi.org/10.12688/f1000research.7048.1

\section{Abstract}

The spectrum of adverse reactions to blood product transfusion ranges from a benign clinical course to serious morbidity and mortality. There have been many advances in technologies and transfusion strategies to decrease the risk of adverse reactions. Our aim is to address a few of the advancements in increasing the safety of the blood supply, specifically pathogen reduction technologies, bacterial contamination risk reduction, and transfusion associated acute lung injury risk mitigation strategies.

\section{Keywords}

Blood Transfusion , Transfusion Related Acute Lung Injury, TRALI, Transfusion Associated Circulatory Overload, TACO , Human leukocyte antigens, Human leukocyte antigen antibodies

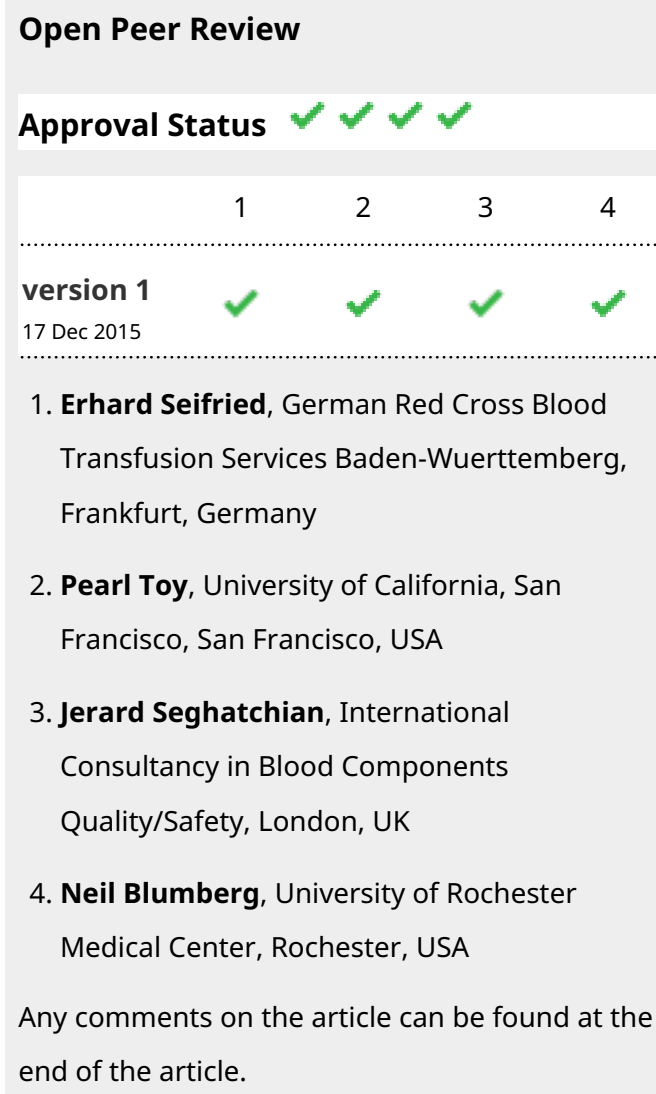

4. Neil Blumberg, University of Rochester Medical Center, Rochester, USA

Any comments on the article can be found at the end of the article.

Corresponding author: Thomas S Rogers (thomas.rogers@uvmhealth.org)

Competing interests: The authors declare that they have no competing interests.

Grant information: The author(s) declared that no grants were involved in supporting this work.

Copyright: $\odot 2015$ Rogers TS et al. This is an open access article distributed under the terms of the Creative Commons Attribution License, which permits unrestricted use, distribution, and reproduction in any medium, provided the original work is properly cited.

How to cite this article: Rogers TS, Fung MK and Harm SK. Recent Advances in Preventing Adverse Reactions to Transfusion [version 1; peer review: 4 approved] F1000Research 2015, 4(F1000 Faculty Rev):1469 https://doi.org/10.12688/f1000research.7048.1

First published: 17 Dec 2015, 4(F1000 Faculty Rev):1469 https://doi.org/10.12688/f1000research.7048.1 


\section{Introduction}

The transfusion of blood products is never without risk. Complications such as transfusion-transmitted infectious diseases (TTIDs), antibody formation to red and white blood cells, preformed cytokines, and sudden increases in intravascular volume, to name a few, may result in severe health consequences to the transfusion recipient. A large focus of the transfusion medicine community has been to decrease the risk of TTIDs such as human immunodeficiency virus (HIV), hepatitis B, and hepatitis C (see Table 1) through extensive donor infectious disease testing, removal of monetary compensation to blood donors, and enhancement of the donor health history questionnaire ${ }^{1-4}$. Despite the successes in reducing the risk of TTIDs, there remain the risks of sepsis due to bacterial contamination, transmission of unknown pathogens, and numerous non-infectious complications, some of which have emerged as leading causes of fatalities due to blood product transfusion.

In 2014, transfusion-related acute lung injury (TRALI) was the leading cause of death due to blood product transfusion in the United States, followed by transfusion-associated circulatory overload (TACO) ${ }^{5}$. Since $2010,41 \%$ of transfusion-related fatalities were due to TRALI, $22 \%$ due to TACO, and microbial infection accounted for $8 \%$ (see Table 2). Unfortunately, there are no laboratory tests to prevent TACO in transfusion recipients. Thus,

Table 1. Transfusion-transmitted viruses. Current testing of blood donors miss these viruses if the donors are in the "window period" when they are infected but do not yet test positive ${ }^{1-4}$.

\begin{tabular}{|c|c|}
\hline Transfusion-transmitted viruses & Risk per unit transfused \\
\hline Human immunodeficiency virus & $1: 1,000,000$ to $1: 5,000,000$ \\
\hline Hepatitis C virus & $1: 1,100,000$ to $1: 10,000,000$ \\
\hline Hepatitis B virus & $1: 400,000$ to $1: 1,200,000$ \\
\hline
\end{tabular}

Table 2. Transfusion fatalities reported to the Food and Drug Administration in the United States from fiscal year (FY) 2010 to FY2014 ${ }^{5}$.

\begin{tabular}{|c|c|c|}
\hline Causes & $\begin{array}{c}\text { No. Cases } \\
\text { FY2010-FY2014 }\end{array}$ & $\%$ \\
\hline TRALI and possible TRALI & 72 & 41 \\
\hline TACO & 38 & 22 \\
\hline $\begin{array}{c}\text { Hemolytic transfusion reaction } \\
\text { (non-ABO) }\end{array}$ & 25 & 14 \\
\hline $\begin{array}{c}\text { Microbial infection } \\
\text { Hemolytic transfusion reaction } \\
\text { (ABO) }\end{array}$ & 15 & 8 \\
\hline Anaphylaxis & 13 & 7 \\
\hline Other* & 10 & 6 \\
\hline TOTAL & 3 & 2 \\
\hline
\end{tabular}

Other: FY2010 and FY2011: Graft vs. host disease FY2014: Hypotensive reaction transfusion services are left with tools such as physician and patient education to recognize clinical signs and symptoms of TACO and help clinicians identify which patients might be most sensitive to sudden increases in intravascular volume. On the other hand, there are newer testing-based strategies to help prevent both TRALI and microbial infection, which once universally incorporated should further reduce the risk of these complications of transfusion.

Additional non-infectious complications of transfusion, while not the leading causes of death, pose serious risks to recipients of blood products. Immunomodulation, nosocomial infection, and other consequences of biologic response modifiers (i.e. byproducts of the red blood cell and platelet storage lesion) may lead to transfusion-related morbidity and mortality ${ }^{6-8}$. Mitigation of these risks may include leukoreduction, byproduct removal by saline washing blood products, and/or using a restrictive transfusion strategy $^{9-11}$. A recent meta-analysis showed that a restrictive transfusion strategy in patients with critical illness or bleeding, using a hemoglobin transfusion trigger of $<7 \mathrm{~g} / \mathrm{dL}$, resulted in a significant reduction in cardiac events, rebleeding, bacterial infections, and total mortality when compared to a less restrictive (more liberal) strategy ${ }^{12}$. However, it is well known that certain patient populations (e.g. acute coronary syndrome) may require higher hemoglobin transfusion triggers ${ }^{13}$. In addition, recent randomized controlled clinical trials in critical care and cardiac surgery patients showed no difference in mortality when receiving fresh versus older red blood cell units $^{14,15}$. Therefore, judicious use of blood products and avoidance of unnecessary transfusion in combination with leukoreduction (and saline washing when clinically indicated) provides the best defense against many of the non-infectious complications of transfusion.

Despite the best efforts of the transfusion medicine community, infectious and non-infectious risks of transfusion remain a problem for transfusion recipients. Ongoing studies continue to discover the consequences of blood product storage, the impact biologic response modifiers have on patient outcomes, the optimal triggers for transfusion, and the detection of pathogens in the blood supply. As we cannot address each and every improvement the transfusion medicine community has made to make the blood supply as safe as possible, we will briefly describe some of the newer strategies adopted by blood centers and hospital transfusion services to help prevent adverse reactions to blood product transfusions. Specifically, we will discuss general pathogen reduction (PR) technologies, improvements that increase the sensitivity of screening for bacterial contamination in platelet products, and the newest TRALI risk mitigation strategies for plasma and platelet products.

\section{Pathogen reduction technologies}

The safety of blood product transfusion has increased greatly due to an extensive donor health history questionnaire and sophisticated donor infectious disease testing, yet the risk of pathogen-related complications in blood product recipients remains. PR technologies include using solvent and detergent, a psoralen compound, or riboflavin, the latter two combined with ultraviolet light, to render pathogens non-infectious (see Table 3$)^{16}$. The goal of PR is zero risk from existing and emerging pathogens in blood products. New technologies reduce but unfortunately do not eliminate the risk of 
Table 3. Pathogen Reduction technology development and approval ${ }^{16,19,20}$.

\begin{tabular}{|c|c|c|c|}
\hline Component & Company & Technique & Status \\
\hline \multirow[t]{4}{*}{ Plasma } & Cerus Corporation INTERCEPT'М & Amotosalen + UVA light & $\begin{array}{l}\text { - CE marked } 2006 \\
\text { - FDA approved } 2014\end{array}$ \\
\hline & Terumo BCT Mirasol ${ }^{\circledR}$ & Riboflavin + UV light & - CE marked 2008 \\
\hline & Macopharma Theraflex ${ }^{\circledR}$ & UVC (254nm) light & - CE marked 2009 \\
\hline & Octapharma OctaPlas ${ }^{\circledR}$ & Solvent detergent & $\begin{array}{l}\text { - CE marked } 2009 \\
\text { - FDA approved } 2013\end{array}$ \\
\hline \multirow[t]{3}{*}{ Platelets } & Cerus Corporation INTERCEPTTM & Amotosalen + UVA light & $\begin{array}{l}\text { - CE marked } 2002 \\
\text { - FDA approved } 2014\end{array}$ \\
\hline & Terumo BCT Mirasol ${ }^{\circledR}$ & Riboflavin + UV light & $\begin{array}{l}\text { - CE marked } 2007 \\
\text { - U.S. phase III clinical } \\
\text { trial planned }\end{array}$ \\
\hline & Macopharma Theraflex ${ }^{\circledR}$ & Methylene blue + visible light & - CE marked 2001 \\
\hline \multirow[t]{2}{*}{ Red Blood Cells } & Cerus Corporation INTERCEPTTM & S303 & $\begin{array}{l}\text { - U.S. phase II and } \\
\text { European phase III } \\
\text { clinical trials completed }\end{array}$ \\
\hline & Terumo BCT Mirasol ${ }^{\circledR}$ & Riboflavin + UV light & $\begin{array}{l}\text { - U.S. phase II clinical } \\
\text { trial completed; phase } \\
\text { III clinical trial planned }\end{array}$ \\
\hline
\end{tabular}

$\mathrm{CE}=$ Conformité Européenne

FDA = Food and Drug Administration

viruses and microbial infection, mentioned in both Table 1 and Table 2. For example, certain Klebsiella pneumonia and Bacillus cereus microbes are not $100 \%$ killed by $\mathrm{PR}^{17,18}$. PR technologies have been slow to market in the United States as opposed to Europe, where PR has been in use for over 10 years (see Table 3$)^{16,19,20}$. While PR technology for platelets and plasma is in its infancy in the United States, the European experience has been positive, with only two transfusion-transmitted infections out of 1681 transfusionrelated incidents reported in $2014^{21}$. In addition, a report on over 50,000 PR plasma transfusions showed no significant difference in adverse events (mostly allergic in nature) compared to non-PR plasma ${ }^{22}$. PR for red blood cells is still in United States phase 2 and European phase 3 studies. Potential benefits of PR red blood cells include reducing the risk of current transfusiontransmitted infections to essentially zero, albeit with risks including alloimmunization and increased cost; however, the true rate of transfusion-transmitted infections has yet to be determined ${ }^{4}$.

There is evidence for the PR systems available for platelets and plasma that most pathogens are inactivated, except for some nonenveloped viruses and certain bacterial strains ${ }^{18,19}$. Thus, there remains a need to screen donors for pathogens that may not be inactivated by the PR method. Additional critiques of PR technologies include a sizable cost increase compared to untreated products, negative effects on platelet function and count, acute respiratory distress syndrome (ARDS), and the potentially associated increased risk of bleeding in transfusion recipients ${ }^{17,23}$. The cost increase of PR technologies has been shown to be offset by the ability to extend the storage time of platelet products and the decreased rate of transfusion-related sepsis ${ }^{24}$. While in vitro measures of adhesion and aggregation in PR platelets is comparable to untreated platelets, in vivo measures of posttransfusion corrected count increments and recovery are lower with PR platelets than untreated platelets ${ }^{25-27}$. Despite in vitro and in vivo study results, there remains equipoise over the clinical bleeding risk in patients who receive PR platelets compared to untreated platelets. For recipients of PR platelets, a Cochrane Review found no significant difference in clinically significant or severe bleeding, mortality, transfusion reactions, or adverse events (including sepsis and transfusion-transmitted infection) compared to recipients of untreated platelets ${ }^{27}$. However, recipients of PR platelets generally require more platelet transfusions, thus more donor exposure, due to poor post-transfusion increments.

The numerous PR technologies available reflect the complexity of finding a balance between effective PR and preserving acceptable quality and functionality of the blood components. In addition to the decreased risk of bacterial contamination and TTIDs, PR technologies provide additional benefits of prevention of transfusion-associated graft-versus-host disease (GVHD), prevention of cytomegalovirus (CMV) disease transmission, and possible reduction of alloimmunization due to inactivation of white blood cells that remain in the blood products. While PR technologies may be a very good defense against emerging TTIDs, there remain concerns over cost, toxicity, alloimmunization, and cellular function (i.e. bleeding risk). As with most new technologies, additional studies are needed to ensure PR blood products are as effective as untreated products in preventing bleeding and adverse events in transfusion recipients. Current PR technologies are a step in the right direction; however, there remains a need to develop safer and better technologies that kill all pathogens. 


\section{Bacterial contamination risk reduction}

Transfusion-related microbial infections range in severity from a mild, transient temperature increase to acute lung injury, fulminant septic shock, and death. While there was only one fatality due to sepsis reported to the Food and Drug Administration (FDA) in fiscal year 2014, clinical sepsis is reported after 1 in every 100,000 platelet transfusions ${ }^{5,16}$. Blood collection centers have implemented a combination of techniques to reduce the risk of microbial contamination in the final blood product, including improved disinfection methods for the venipuncture site, introduction of the diversion pouch during the blood collection procedure, and automated bacterial culture of platelet products, as well as platelet additive solutions and PR systems. Newer developments in bacterial detection (i.e. nucleic acid testing and bio-chip technology) may be on the horizon but unfortunately have not been widely adopted or approved for use throughout the world. At the receiving end, hospital transfusion services have the ability to perform either culture or rapid, non-culture-based bacterial screening tests for platelet products that are at high risk for bacterial contamination at the time of issue. While the interventions described attempt to reduce the risk of fatal bacterial infection in Table 2, they do not provide protection from viral, protozoan, or other pathogens.

The leading sources of blood product contamination are skin bacteria from the venipuncture site during the blood collection procedure. Platelet products are especially susceptible to bacterial growth due to room temperature storage for up to 5 days. After disinfection with povidone iodine or isopropyl alcohol plus iodine tincture, only half of all donors will have remaining bacterial colonies when the venipuncture site is cultured ${ }^{1}$. Unfortunately, bacteria in the deeper skin layers cannot be removed by simple skin disinfection, thus a diversion pouch is required in any collection system intended for preparation of a platelet product ${ }^{28}$. The diversion pouch is integrally attached to the blood product collection set and collects the first few milliliters of whole blood, including any potential skin plug within the access needle, thus diverting the contaminating skin bacteria away from the final blood product container. The combination of skin disinfection with iodine-containing solutions and use of the diversion pouch effectively decreases the risk of bacterial contamination in platelet products ${ }^{29}$.

Unfortunately, there remains a residual risk of bacterial contamination in platelet products despite the improved arm preparation techniques and use of the diversion pouch. Since 2004, the AABB Standards require testing of $100 \%$ of platelet products for bacterial contamination $^{28}$. For apheresis platelets, aliquots from the platelet product are generally drawn 18-24 hours after collection and used to inoculate aerobic cultures using one of the two bacterial detection systems cleared by the FDA for quality control testing of platelets. However, culture data and clinical reports show that even bacterial culture, the gold standard for bacterial detection, can fail to detect all contaminated platelet units ${ }^{30,31}$. For whole-bloodderived platelet products, an alternative to culture is the use of an FDA-cleared rapid bacterial detection test at the time of product issue. Unfortunately, these tests carry a high false-positive rate and result in the unnecessary discard of platelet products ${ }^{32}$. However, the rapid bacterial detection tests have been successfully used to allow for the extension of apheresis platelet shelf life in times of medical necessity and help ensure that platelet products, especially day 4 and 5 , are free of clinically significant levels of bacterial contamination $^{33}$. Thus, the Blood Product Advisory Committee (BPAC) has made recommendations to take precautions in order to decrease the risk of bacterial contamination of blood products.

In 2012, BPAC released a report recommending that blood centers and transfusion services either modify or perform additional testing on platelet products to help reduce the risk of recipient fatality due to bacterial contamination ${ }^{34}$. Then, in 2014, the FDA released industry guidance in line with the BPAC report to enhance the safety of platelet transfusions ${ }^{35}$. Recommendations for apheresis and pre-storage pooled platelets include testing for bacterial contamination using an FDA-cleared device no sooner than 24 hours post-collection and inoculating at least an aerobic culture medium, sampling the maximum volume permitted by the manufacturer of the culture device and considering increased sample volumes in proportion to collection volume (i.e. double and triple platelet collections) to maximize primary culture sensitivity, and adhering to the minimal incubation period described by the bacterial detection device manufacturer. Recommendations for whole-blood-derived platelets that are pooled at the time of issue and not previously tested for bacterial contamination include either culture as described for apheresis platelets or the use of a rapid bacterial detection device no sooner than 72 hours after collection. Thus, both the timing and the volume of the sample drawn for bacterial culture is important to help decrease the risk of sepsis due to bacterial contamination in platelet products.

While blood centers can adopt strategies to improve detection of bacterial contamination in platelet products, hospital transfusion services can take additional precautions to prevent septic transfusion reactions. As septic transfusion reactions and fatalities are more common on days 4 and 5 of storage, after initially low inoculums of bacteria are allowed to grow to clinically significant levels, the BPAC report and FDA guidance document also recommended the use of either a rapid bacterial screening test or re-culture of the platelet product on days 4 and 5 of storage ${ }^{34,35}$. Transfusion services have also successfully adopted a strategy of screening for bacterial contamination on day 4 or 5 of storage to extend the expiry of platelet products to 7 days when there is urgent clinical need with no increase in the rate of septic transfusion reactions ${ }^{33}$. While no bacterial detection system is perfect, the combination of culture and rapid screening tests may provide the best risk reduction strategy for platelet transfusion-related septic reactions and safely extend the expiry date of the transfusion service's most limited resource.

\section{TRALI risk mitigation strategies}

TRALI is a severe transfusion reaction characterized by the acute onset of new, non-cardiogenic pulmonary edema that occurs within 6 hours of transfusion. Most cases of TRALI result from cognate antibodies between recipient human leukocyte antigens (HLA) on white blood cells and HLA antibodies in donor plasma. HLA antibodies are formed after exposure to foreign white blood cells. Thus, recipients of blood products replete with white blood cells, females who have been pregnant and exposed to fetal white blood cells, and recipients of solid organ or bone marrow transplants are most likely to develop HLA antibodies. 
The prevalence of HLA antibodies in female donors is related to the number of prior pregnancies ${ }^{36}$. Consequently, when comparing men and nulliparous women to previously pregnant donors, transfusion of blood components, especially apheresis plasma, carries a higher risk of inducing TRALI ${ }^{37}$. While previous transfusion increases the overall risk of developing HLA antibodies, a study of donors who had received a transfusion greater than 12 months prior to enrollment revealed that the incidence of HLA antibodies was not significantly increased compared to non-transfused donors ${ }^{38}$. Thus, a remote transfusion history in donors does not significantly contribute to an increased risk of HLA antibodies and these donors should not be excluded as part of TRALI risk mitigation strategies. Given the available evidence, in 2006, blood centers in the United States began restricting a large portion of plasma collections to males and nulliparous females. Subsequently, two separate analyses showed that a male-predominant plasma strategy has been associated with a reduction in TRALI cases $^{39,40}$.

Then, in 2014, due to the observed residual risk of TRALI, the AABB Standard 5.4.1.2 stated that "plasma and whole blood for allogeneic transfusion shall be from males, females who have not been pregnant, or females who have been tested since their most recent pregnancy and results interpreted as negative for HLA antibodies" 28 . Any donor who is found to be HLA antibody positive is not eligible for future donations of apheresis plasma or whole-blood-derived plasma for transfusion, while a negative result permits the release of all subsequent plasma components unless or until the donor becomes pregnant.

Therefore, blood collection facilities have two options to meet the AABB Standard: either perform HLA antibody screening on all female donors instead of taking a pregnancy history on all donors whose donation produces transfusable plasma components, or target HLA antibody testing for any female who has had any number of pregnancies carried to term or delivered. The estimated impact in loss of parous female donors must be weighed against targeted HLA testing to arrive at the best TRALI risk reduction strategy.

There has been some evidence suggesting human neutrophil antigen (HNA) antibodies may play a role in the development of TRALI, but due to their low prevalence in the donor population and the fact that they require specialized testing not conducive to large-scale screening, there is no compelling data to adopt screening for HNA antibodies ${ }^{41}$. In addition, the fact that HLA antibody co-occurred in the majority of HNA antibody-positive donors suggests HNA-positive blood products may already be reduced as a consequence of HLA antibody screening.

Despite the current decreased incidence of TRALI with modified transfusion practices, it is still the leading cause of transfusionrelated fatalities in the United States ${ }^{5}$. However, it should be recognized that the FDA fatality reports through fiscal year 2014 include both TRALI and possible TRALI cases, the latter of which are most likely ARDS cases and not related to transfusion ${ }^{42}$. Thus, plasma mitigation strategies will not decrease the incidence of possible TRALI. It is therefore paramount that clinicians recognize, diagnose, and report TRALI and TRALI-related mortality to the blood bank so that incidence, pathophysiology, and strategies to prevent this leading cause of transfusion-associated mortality can be further studied.

\section{Conclusion}

The blood supply is the safest it has been in decades, yet blood centers and transfusion services continue to pursue massive efforts to prevent the infectious and non-infectious complications associated with blood product transfusion. One major challenge is to identify and stay one step ahead of emerging pathogens that threaten the safety of transfusable blood components. While blood centers continue to harness PR technologies and improve upon current pathogen detection techniques to enhance the safety of blood products, a challenge will be to keep the cost-benefit ratio of new technologies in check. Meanwhile, transfusion services will continue to struggle with the many non-infectious complications of transfusion. For example, despite the risk mitigation strategies implemented to date for plasma and platelet products, TRALI remains the leading cause of transfusion-related mortality, with red blood cell units now emerging as the implicated blood product. A challenge for the transfusion medicine community will be to further decrease the risk of TRALI while maintaining a healthy balance between the eligible donor pool and blood product inventory. While challenges remain for both blood centers and hospital transfusion services, the recent successes and strides made towards increasing the safety of the blood supply are noteworthy.

\section{Competing interests}

The authors declare that they have no competing interests.

\section{Grant information}

The author(s) declared that no grants were involved in supporting this work.
1. Fung MK: Technical Manual. 18th ed: AABB; 2014.

2. Roth WK, Busch MP, Schuller A, et al:: International survey on NAT testing of blood donations: expanding implementation and yield from 1999 to 2009. Vox Sang. 2012; 102(1): 82-90.

PubMed Abstract | Publisher Full Text

3. Zou S, Stramer SL, Dodd RY: Donor testing and risk: current prevalence, incidence, and residual risk of transfusion-transmissible agents in US allogeneic donations. Transfus Med Rev. 2012; 26(2): 119-28. PubMed Abstract | Publisher Full Text
4. Kleinman S, Stassinopoulos A: Risks associated with red blood cell transfusions: potential benefits from application of pathogen inactivation. Transfusion. 2015

PubMed Abstract | Publisher Full Text

5. Fatalities Reported to FDA Following Blood Collection and Transfusion: Annual Summary for Fiscal Year 2014. 2014. Reference Source

6. Goubran HA, Burnouf T, Stakiw J, et al.: Platelet microparticle: a sensitive physiological "fine tuning" balancing factor in health and disease. 
Transfus Apher Sci. 2015; 52(1): 12-8.

PubMed Abstract | Publisher Full Tex

7. Varon $\mathrm{D}$, Shai $\mathrm{E}$ : Role of platelet-derived microparticles in angiogenesis and tumor progression. Discov Med. 2009; 8(43): 237-41. PubMed Abstract

8. F Rubin O, Delobel J, Prudent M, et al:: Red blood cell-derived microparticles isolated from blood units initiate and propagate thrombin generation. Transfusion. 2013; 53(8): 1744-54. PubMed Abstract | Publisher Full Text | F1000 Recommendation

9. $\quad F$ Rohde JM, Dimcheff DE, Blumberg N, et al.: Health care-associated infection after red blood cell transfusion: a systematic review and meta-analysis. JAMA. 2014; 311(13): 1317-26.

PubMed Abstract | Publisher Full Text | Free Full Text | F1000 Recommendation

10. Lannan KL, Sahler J, Spinelli SL, et al:: Transfusion immunomodulation--the case for leukoreduced and (perhaps) washed transfusions. Blood Cells Mol Dis. 2013; 50(1): 61-8.

PubMed Abstract | Publisher Full Text | Free Full Text

11. F Cholette JM, Henrichs KF, Alfieris GM, et al:: Washing red blood cells and platelets transfused in cardiac surgery reduces postoperative inflammation and number of transfusions: results of a prospective, randomized, controlled clinical trial. Pediatr Crit Care Med. 2012; 13(3): 290-9.

PubMed Abstract | Publisher Full Text | Free Full Text | F1000 Recommendation

12. F Salpeter SR, Buckley JS, Chatterjee S: Impact of more restrictive blood ransfusion strategies on clinical outcomes: a meta-analysis and systematic review. Am J Med. 2014; 127(2): 124-131.e3. PubMed Abstract | Publisher Full Text | F1000 Recommendation

13. F Carson JL, Brooks MM, Abbott JD, et al.: Liberal versus restrictive transfusion thresholds for patients with symptomatic coronary artery disease. Am Heart J. 2013; 165(6): 964-971.e1.

PubMed Abstract | Publisher Full Text | Free Full Text | F1000 Recommendation

14. F Lacroix J, Hébert PC, Fergusson DA, et al: Age of transfused blood in critically ill adults. N Engl J Med. 2015; 372(15): 1410-8.

PubMed Abstract | Publisher Full Text | F1000 Recommendation

15. F Steiner ME, Ness PM, Assmann SF, et al.: Effects of red-cell storage duration on patients undergoing cardiac surgery. N Engl J Med. 2015; 372(15): 1419-29.

PubMed Abstract | Publisher Full Text | F1000 Recommendation

16. Snyder EL, Stramer SL, Benjamin RJ: The safety of the blood supply--time to raise the bar. N Engl J Med. 2015; 372(20): 1882-5.

PubMed Abstract | Publisher Full Text

17. Jacobs MR, Lazarus HM, Maitta RW: The Safety of the Blood Supply--Time to Raise the Bar. N Engl J Med. 2015; 373(9): 882.

PubMed Abstract | Publisher Full Text

18. F Schmidt M, Hourfar MK, Sireis W, et al:: Evaluation of the effectiveness of a pathogen inactivation technology against clinically relevant transfusiontransmitted bacterial strains. Transfusion. 2015; 55(9): 2104-12. PubMed Abstract | Publisher Full Text | F1000 Recommendation

19. Prowse CV: Component pathogen inactivation: a critical review. Vox Sang 2013; 104(3): 183-99.

PubMed Abstract | Publisher Full Tex

20. AuBuchon JP, Prowse CV, AABB: Pathogen inactivation: the penultimate paradigm shift. Bethesda, Md.: AABB Press; 2010; 294. Reference Source

21. Bolton-Maggs $P(E d)$, Poles $D$, Thomas $D$, et al: On behalf of the Serious Hazards of Transfusion (SHOT) Steering Group: The 2014 Annual SHOT Report. 2015. Reference Source

22. $F$ Bost $V$, Chavarin $P$, Boussoulade $F$, et al.: Independent evaluation of tolerance of therapeutic plasma inactivated by amotosalen-HCl-UVA (Intercept $^{\mathrm{TM}}$ ) over a 5-year period of extensive delivery. Vox Sang. 2015; 109(4): 414-6.

PubMed Abstract | Publisher Full Text | F1000 Recommendation

23. Lozano M, Cid J: Analysis of reasons for not implementing pathogen inactivation for platelet concentrates. Transfus Clin Biol. 2013; 20(2): 158-64. PubMed Abstract | Publisher Full Tex

24. F Girona-Llobera E, Jimenez-Marco T, Galmes-Trueba A, et al:: Reducing the financial impact of pathogen inactivation technology for platelet components: our experience. Transfusion. 2014; 54(1): 158-68.

PubMed Abstract | Publisher Full Text | F1000 Recommendation

25. F Snyder E, Raife T, Lin L, et al.: Recovery and life span of ${ }^{111}$ indium adiolabeled platelets treated with pathogen inactivation with amotosalen $\mathrm{HC}$
(S-59) and ultraviolet A light. Transfusion. 2004; 44(12): 1732-40. PubMed Abstract | Publisher Full Text | F1000 Recommendation

26. F Slichter SJ, Raife TJ, Davis K, et al:: Platelets photochemically treated with amotosalen $\mathrm{HCl}$ and ultraviolet $\mathrm{A}$ light correct prolonged bleeding times in patients with thrombocytopenia. Transfusion. 2006; 46(5): 731-40. PubMed Abstract | Publisher Full Text | F1000 Recommendation

27. F Butler C, Doree C, Estcourt LJ, et al:: Pathogen-reduced platelets for the prevention of bleeding. Cochrane Database Syst Rev. 2013; 3: CD009072. PubMed Abstract | Publisher Full Text | F1000 Recommendation

28. Standards for blood banks and transfusion services. 29th ed. Bethesda, MD: AABB; 2014

Reference Source

29. F de Korte D, Curvers J, de Kort WL, et al: Effects of skin disinfection method, deviation bag, and bacterial screening on clinical safety of platelet transfusions in the Netherlands. Transfusion. 2006; 46(3): 476-85. PubMed Abstract | Publisher Full Text | F1000 Recommendation

30. F Dumont LJ, Kleinman S, Murphy JR, et al:: Screening of single-donor apheresis platelets for bacterial contamination: the PASSPORT study results. Transfusion. 2010; 50(3): 589-99. PubMed Abstract | Publisher Full Text | F1000 Recommendation

31. F Jacobs MR, Smith D, Heaton WA, et al.: Detection of bacterial contamination n prestorage culture-negative apheresis platelets on day of issue with the Pan Genera Detection test. Transfusion. 2011; 51(12): 2573-82.

PubMed Abstract | Publisher Full Text | F1000 Recommendation

32. Harm SK, Delaney M, Charapata M, et al.: Routine use of a rapid test to detect bacteria at the time of issue for nonleukoreduced, whole blood-derived platelets. Transfusion. 2013; 53(4): 843-50. PubMed Abstract | Publisher Full Text

33. F Dunbar NM, Kreuter JD, Marx-Wood CR, et al:: Routine bacterial screening of apheresis platelets on Day 4 using a rapid test: a 4-year single-center experience. Transfusion. 2013; 53(10): 2307-13.

PubMed Abstract | Publisher Full Text | F1000 Recommendation

34. (BPAC) BPAC: Considerations for Options to Further Reduce the Risk of Bacterial Contamination in Platelets. 2012. Reference Source

35. U.S. Department of Health and Human Services FDA: Bacterial Detection Testing by Blood Collection Establishments and Transfusion Services to Enhance the Safety and Availability of Platelets for Transfusion. 2014.

Reference Source

36. F Triulzi DJ, Kleinman S, Kakaiya RM, et al:: The effect of previous pregnancy nd transfusion on HLA alloimmunization in blood donors: implications for a transfusion-related acute lung injury risk reduction strategy. Transfusion. 2009; 49(9): 1825-35.

PubMed Abstract | Publisher Full Text | Free Full Text | F1000 Recommendation

37. F Kleinman SH, Triulzi DJ, Murphy EL, et al:: The Leukocyte Antibody Prevalence Study-II (LAPS-II): a retrospective cohort study of transfusionrelated acute lung injury in recipients of high-plasma-volume human leukocyte antigen antibody-positive or -negative components. Transfusion. 2011; 51(10): 2078-91

PubMed Abstract | Publisher Full Text | Free Full Text | F1000 Recommendation

38. F Kakaiya RM, Triulzi DJ, Wright DJ, et al:: Prevalence of HLA antibodies in remotely transfused or alloexposed volunteer blood donors. Transfusion. 2010; 50(6): 1328-34.

PubMed Abstract | Publisher Full Text | Free Full Text | F1000 Recommendation

39. F SchmickI CN, Mastrobuoni S, Filippidis FT, et al:: Male-predominant plasma transfusion strategy for preventing transfusion-related acute lung injury: a systematic review. Crit Care Med. 2015; 43(1): 205-25. PubMed Abstract | Publisher Full Text | F1000 Recommendation

40. F Müller MC, van Stein D, Binnekade JM, et al.: Low-risk transfusion-related acute lung injury donor strategies and the impact on the onset of transfusionrelated acute lung injury: a meta-analysis. Transfusion. 2015; 55(1): 164-75. PubMed Abstract | Publisher Full Text | F1000 Recommendation

41. F Gottschall JL, Triulzi DJ, Curtis B, et al.: The frequency and specificity of human neutrophil antigen antibodies in a blood donor population. Transfusion. 2011; 51(4): 820-7.

PubMed Abstract | Publisher Full Text | Free Full Text | F1000 Recommendation

42. F Toy $P$, Bacchetti $P$, Grimes B, et al.: Recipient clinical risk factors predominate in possible transfusion-related acute lung injury. Transfusion. 2015; 55(5): 947-52.

PubMed Abstract | Publisher Full Text | Free Full Text | F1000 Recommendation 


\section{Open Peer Review}

\section{Current Peer Review Status:}

\section{Version 1}

Reviewer Report 17 December 2015

https://doi.org/10.5256/f1000research.7588.r11483

(C) 2015 Blumberg N. This is an open access peer review report distributed under the terms of the Creative Commons Attribution License, which permits unrestricted use, distribution, and reproduction in any medium, provided the original work is properly cited.

\section{Neil Blumberg}

Department of Pathology and Laboratory Medicine, University of Rochester Medical Center, Rochester, New York, 14642, USA

The relatively recently described complications of nosocomial infection, thrombosis and multiorgan failure that are caused, in part, by allogeneic red cell transfusion affect $1-2 \%$ of transfused patients, at minimum (1-4). These are severe and life threatening acute morbidities that are rarely mentioned in current textbooks and reviews, but well characterized in randomized trials of restrictive transfusion practices (2,3), autologous transfusion (5) and leukoreduced (1) transfusions. Thus mitigating the side effects of transfusion includes strategies such as restrictive red cell transfusion where validated in randomized trials, universal leukoreduction of transfusions, and implementation of blood management programs including techniques for minimizing the need for allogeneic transfusion. Such techniques can include various types of autologous transfusion (normovolemic hemodilution, cell salvage) and minimization of iatrogenic or surgical blood loss, as well as anemia management and pharmacologic approaches that mitigate anemia and thrombocytopenia.

There is also preliminary data that removal of supernatant from transfused red cells and platelets may benefit patients undergoing cardiac surgery (6) and those treated for acute leukemia (7). Animal models support these possible benefits of washed transfusions (8).

In addition, there is a growing body of evidence that $A B O$ non-identical transfusions interfere with normal hemostasis, increase bleeding and mortality in hospitalized patients (9-13). Use of ABO identical transfusions is associated with reduced transfusion reactions, lung injury, alloimmunization and death in epidemiologic observational studies. While these data are still preliminary, they derive from multiple institutions and clinical settings, and have credible mechanistic explanations. $A B O$ identical transfusions may be one key strategy to improve clinical outcomes in the future. (14)

\section{References}

1. Fergusson D, Khanna MP, Tinmouth A, Hébert PC: Transfusion of leukoreduced red blood cells may decrease postoperative infections: two meta-analyses of randomized controlled trials. Can J Anaesth. 2004; 51 (5): 417-24 PubMed Abstract | Publisher Full Text 
2. Salpeter SR, Buckley JS, Chatterjee S: Impact of more restrictive blood transfusion strategies on clinical outcomes: a meta-analysis and systematic review.Am J Med. 2014; 127 (2): 124-131.e3 PubMed Abstract | Publisher Full Text

3. Rohde JM, Dimcheff DE, Blumberg N, Saint S, et al.: Health care-associated infection after red blood cell transfusion: a systematic review and meta-analysis.JAMA. 2014; 311 (13): 1317-26 PubMed Abstract | Publisher Full Text

4. Robertson CS, Hannay HJ, Yamal JM, Gopinath S, et al.: Effect of erythropoietin and transfusion threshold on neurological recovery after traumatic brain injury: a randomized clinical trial.JAMA. 2014; 312 (1): 36-47 PubMed Abstract | Publisher Full Text

5. Vanderlinde ES, Heal JM, Blumberg N: Autologous transfusion.BMJ. 2002; 324 (7340): 772-5 PubMed Abstract

6. Cholette JM, Henrichs KF, Alfieris GM, Powers KS, et al.: Washing red blood cells and platelets transfused in cardiac surgery reduces postoperative inflammation and number of transfusions: results of a prospective, randomized, controlled clinical trial.Pediatr Crit Care Med. 2012; 13 (3): 2909 PubMed Abstract | Publisher Full Text

7. Blumberg N, Heal JM, Rowe JM: A randomized trial of washed red blood cell and platelet transfusions in adult acute leukemia [ISRCTN76536440].BMC Blood Disord. 2004; 4 (1): 6 PubMed Abstract | Publisher Full Text

8. Cortés-Puch I, Wang D, Sun J, Solomon SB, et al.: Washing older blood units before transfusion reduces plasma iron and improves outcomes in experimental canine pneumonia.Blood. 2014; 123 (9): 1403-11 PubMed Abstract | Publisher Full Text

9. Blumberg N, Heal JM, Hicks GL, Risher WH: Association of ABO-mismatched platelet transfusions with morbidity and mortality in cardiac surgery.Transfusion. 2001; 41 (6): 790-3 PubMed Abstract 10. Inaba K, Branco BC, Rhee $P$, Holcomb JB, et al.: Impact of ABO-identical vs ABO-compatible nonidentical plasma transfusion in trauma patients.Arch Surg. 2010; 145 (9): 899-906 PubMed Abstract | Publisher Full Text

11. Shanwell A, Andersson TM, Rostgaard K, Edgren G, et al.: Post-transfusion mortality among recipients of ABO-compatible but non-identical plasma.Vox Sang. 2009; 96 (4): 316-23 PubMed Abstract | Publisher Full Text

12. Henrichs KF, Howk N, Masel DS, Thayer M, et al.: Providing ABO-identical platelets and cryoprecipitate to (almost) all patients: approach, logistics, and associated decreases in transfusion reaction and red blood cell alloimmunization incidence.Transfusion. 2012; 52 (3): 63540 PubMed Abstract | Publisher Full Text

13. Zaffuto BJ, Conley GW, Connolly GC, Henrichs KF, et al.: ABO-immune complex formation and impact on platelet function, red cell structural integrity and haemostasis: an in vitro model of $A B O$ non-identical transfusion.Vox Sang. 2015. PubMed Abstract | Publisher Full Text

14. Pai M, Cook R, Barty R, Eikelboom J, et al.: Exposure to ABO-nonidentical blood associated with increased in-hospital mortality in patients with group A blood.Transfusion. 2015. PubMed Abstract | Publisher Full Text

Competing Interests: No competing interests were disclosed.

\section{I confirm that I have read this submission and believe that I have an appropriate level of expertise to confirm that it is of an acceptable scientific standard.}

Reviewer Report 17 December 2015

https://doi.org/10.5256/f1000research.7588.r11482 
(c) 2015 Seghatchian J. This is an open access peer review report distributed under the terms of the Creative Commons Attribution License, which permits unrestricted use, distribution, and reproduction in any medium, provided the original work is properly cited.

\section{Jerard Seghatchian}

Audit/Inspection and DDR Strategy, International Consultancy in Blood Components

Quality/Safety, London, UK

Competing Interests: No competing interests were disclosed.

I confirm that I have read this submission and believe that I have an appropriate level of expertise to confirm that it is of an acceptable scientific standard.

Reviewer Report 17 December 2015

https://doi.org/10.5256/f1000research.7588.r11480

(C) 2015 Toy P. This is an open access peer review report distributed under the terms of the Creative Commons Attribution License, which permits unrestricted use, distribution, and reproduction in any medium, provided the original work is properly cited.

\section{Pearl Toy}

Department of Laboratory Medicine, University of California, San Francisco, San Francisco, California, 94143, USA

Competing Interests: No competing interests were disclosed.

I confirm that I have read this submission and believe that I have an appropriate level of expertise to confirm that it is of an acceptable scientific standard.

Reviewer Report 17 December 2015

https://doi.org/10.5256/f1000research.7588.r11481

(C) 2015 Seifried E. This is an open access peer review report distributed under the terms of the Creative Commons Attribution License, which permits unrestricted use, distribution, and reproduction in any medium, provided the original work is properly cited.

\section{Erhard Seifried}

German Red Cross Blood Transfusion Services Baden-Wuerttemberg, Frankfurt, D-60528, Germany 
Competing Interests: No competing interests were disclosed.

I confirm that I have read this submission and believe that I have an appropriate level of expertise to confirm that it is of an acceptable scientific standard.

The benefits of publishing with F1000Research:

- Your article is published within days, with no editorial bias

- You can publish traditional articles, null/negative results, case reports, data notes and more

- The peer review process is transparent and collaborative

- Your article is indexed in PubMed after passing peer review

- Dedicated customer support at every stage

For pre-submission enquiries, contact research@f1000.com 